1. MBBS, DMRD, MPH, PhD

(Ultrasound \& Public Health)

Dean Faculty of Allied Health

Sciences

The University of Lahore.

2. MPH, PhD (Public Health USA) Head / Director University Institute of Public Health The University of Lahore

3. MBBS, MPH, MME, PhD (Scholar) Associate Professor,

Community Medicine \& Director, Department of Medical Education Azra Naheed Medical College, The Superior University Lahore

4. MBBS, MS-TQM (Med), MME, PhD Department of Family and Community Medicine, Faculty of Medicine in Rabigh, King Abdul Aziz University, KSA

University Institute of Public Health, The University of Lahore, Pakistan

Correspondence Address:

Dr. Muhammad Zahid Latif

MBBS, MPH, MME, PhD (Scholar)

Associate Professor

Community Medicine \& Director,

Department of Medical Education,

Azra Naheed Medical College Lahore.

mzahidlatif@yahoo.com

Article received on:

03/05/2017

Accepted for publication:

$15 / 10 / 2017$

Received after proof reading:

$29 / 11 / 2017$

\title{
SEROPOSITIVITY OF HEPATITIS C VIRUS; OCCUPATION BASED IN RURAL PUNJAB, PAKISTAN.
}

\begin{abstract}
Syed Amir Gilani', Muhammad Athar Khan², Muhammad Zahid Latif ${ }^{3}$, Ahmad Azam Malik ${ }^{4}$
\end{abstract}
ABSTRACT... Objectives: This study was conducted to find out the occupation based HCV prevalence in the rural communities of Punjab. Settings: Rural communities of Punjab, Pakistan. Study Design: Epidemiological, descriptive, cross sectional study. Study Period: January 2013 to June 2016. Methods: Punjab was divided into three regions. Three districts were selected from each region and from each district three rural union councils were selected. After the approval of institutional review committee, non-probability convenience based sampling technique was adopted and study subjects of different occupations were included in the study. A structured questionnaire was prepared for data collection. Standard procedure for HCV screening was observed. The collected data was organized and entered into version 22 of SPSS for analysis. Results: A total of 1465 subjects related to ten different occupations included in the study and tested for anti HCV antibodies, out of which $323(22 \%)$ were positive. The prevalence was much higher in the collector of hospital garbage (67.2\%) followed by factory workers (30.3\%) and white wash painters (26.6\%) respectively. The lowest prevalence rate was observed in black smith workers (10\%) and carpenters $(5.5 \%)$ only. Conclusion: This study conclude occupation based prevalence rate of (22\%) in rural Punjab. This is a high prevalence which need the immediate attention of the policy makers. It is recommended to manage an occupation based hepatitis awareness and screening campaign for the affected and general community.

Key words: $\quad$ HCV, Anti HCV Antibodies, Occupations, Rural Punjab, Seropositivity.

Article Citation: Gilani SA, Khan MA, Latif MZ, Malik AA. Seropositivity of hepatitis c virus; Occupation based in rural Punjab, Pakistan. Professional Med J 2017;24(12):1835-1839. DOI:10.17957/TPMJ/17.4015

\section{INTRODUCTION}

Hepatitis $C$ virus infection is a widely distributed health problem which is steadily increasing globally. This disease pose a considerable burden in the developed and developing countries. ${ }^{1}$ It is a single-stranded RNA virus of Flaviridae family having eighty plus serotypes. Several HCV genotypes have also been discovered. ${ }^{2}$ Around 170 million individuals are persistently diseased with HCV infection. This disease results in a frightening percentage of $2.2 \%$ of the entire population around the globe. However these statistics vary within and between the countries. ${ }^{3}$ It is difficult to diagnose new cases of $\mathrm{HCV}$ infection because the clinical manifestations of the acute disease is present in only 10 to $25 \%$ of the cases. ${ }^{4}$ The transmission of HCV infection is mostly due to the exposure to infected blood and sexual route. The high risk groups include the health care workers, intravenous drug addicts and sex workers. ${ }^{5}$ Nosocomial infections through needle stick injuries, renal dialysis, infected equipment and other hospital based mode of transmissions can also occur. In addition, vertical and sexual transmission have also been incriminated. ${ }^{6}$

Pakistan is among the countries having endemic presence of Hepatitis C virus. ${ }^{7}$ An increasing number of HCV seropositivity had been reported in different research studies of last few years. A recent research of $\mathrm{HCV}$ sero epidemiology in rural population of Faisalabad region, published in 2015 had reported a prevalence rate of $22.68 .{ }^{8}$ Another study concluded a prevalence rate of $47.4 \%$ seropositivity in the same region. ${ }^{9}$ The reported prevalence of $\mathrm{HCV}$ in Islamabad, the federal capital of Pakistan is $33 \% .{ }^{10}$ Similarly, the concluded prevalence of $\mathrm{HCV}$ was $28.6 \%$ 
in a study conducted at rural and periurban areas of Sindh. ${ }^{11}$ Another study of a village from Kashmir had reported $7.5 \%$ prevalence of HCV seropositivity. ${ }^{12}$

The infection by HCV is among the key public health concerns for health policy makers of Pakistan. ${ }^{13}$ This dilemma becomes a more serious issue due to the asymptomatic condition of the infection resulting in a large number of un-identified cases and carriers of the disease. $\mathrm{HCV}$ infection is more prevalent in developing countries as compared to developed nations. This high rate of the prevalence in developing countries may be due to the lack of health care infrastructure, low level of health literacy and high cost of the treatment. The national health spending is another contributing factor.

It is important to mention that research of occupation related HCV prevalence is generally limited to the studies about health care workers. ${ }^{14,15,16}$ However the relevant literature related to other occupation is inadequate. Keeping in view the gap this study was designed to determine the occupation based HCV prevalence in the rural communities of Punjab, Pakistan. The objective of this study was to find out the occupation based prevalence rate of infection by $\mathrm{HCV}$ in the rural communities of Punjab, Pakistan.

\section{METHODOLOGY}

This was an epidemiological, descriptive and cross sectional study conducted during the period of January 2013 to June 2016 . The objective was to find out the occupation based prevalence of $\mathrm{HCV}$ in rural communities of Punjab, Pakistan. For this purpose the province of Punjab was divided into three sectors including northern, central and southern regions. Three districts were selected from each region and from each district three rural union councils were selected to finalize the study subjects. The selection of rural areas was based on the declared recommendation of the district authorities. Each selected union council was away from the public sector health care facility. After the approval of institutional review committee, non-probability convenience based sampling technique was adopted and study subjects of different occupations were included in the study. A structured questionnaire was prepared for data collection. It was pre tested and necessary changes were made accordingly. Standard procedure for blood sample collection and HCV screening was observed. The results of the screening tests were recorded on the questionnaire along with the occupations of the study subjects. This data was organized and entered into the computer software statistics package for social sciences (SPSS) version 22. It was analyzed and the results are presented in the form of frequencies and percentages.

\section{RESULTS}

A total of 1465 subjects related to ten different occupations included in the study. These participants comprise of the junior rank police officials, workers of factories, mechanic of workshops, cycle mechanics, mechanic of motor cycles, black smith, collector of hospital garbage, painters, carpenters and masons. The study subjects were tested for the positivity of antibodies of HCV. Out of these 1465 subject 323 were positive for anti HCV antibodies with a cumulative prevalence rate of $(22 \%)$. The observed prevalence rate was higher in northern Punjab (25.1\%) as compared to southern (20.8\%) and central Punjab (20.2\%) respectively. The prevalence rate was much higher is subjects related with the collection of hospital garbage $(67.2 \%)$ where as the factory workers were having a prevalence rate of (30.3\%) and white wash painters $(26.6 \%)$ respectively. The lowest prevalence rate was observed in black smith workers (10\%) and carpenters $5.5 \%$ only.

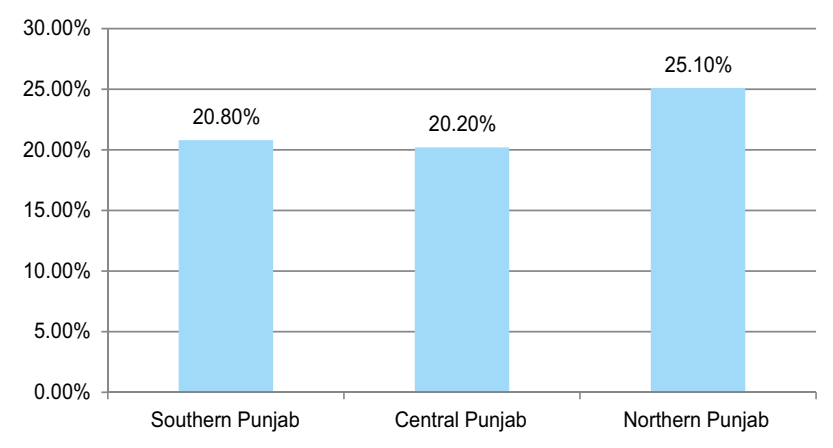

Figure-1. Prevalence of Anti HCV antibodies in different regions of Punjab 


\begin{tabular}{|c|c|c|c|c|c|c|c|c|}
\hline \multirow[b]{2}{*}{ Category } & \multicolumn{2}{|c|}{ Southern Punjab } & \multicolumn{2}{|c|}{ Central Punjab } & \multicolumn{2}{|c|}{ Northern Punjab } & \multicolumn{2}{|l|}{ Total } \\
\hline & $\begin{array}{c}\text { Tests } \\
\text { No. }\end{array}$ & $\begin{array}{c}\text { + ve Test } \\
\text { (\%) }\end{array}$ & $\begin{array}{c}\text { Tests } \\
\text { No. }\end{array}$ & $\begin{array}{l}\text { +ve } \\
\text { Test } \\
\text { (\%) }\end{array}$ & $\begin{array}{c}\text { Tests } \\
\text { No. }\end{array}$ & $\begin{array}{c}\text { + ve Test } \\
\text { (\%) }\end{array}$ & $\begin{array}{l}\text { Tests } \\
\text { No. }\end{array}$ & $\begin{array}{c}\text { +ve Test } \\
\text { (\%) }\end{array}$ \\
\hline Black smith & 10 & $2-(20)$ & 10 & $1-(10)$ & 10 & $0-(0)$ & 30 & $3-(10)$ \\
\hline Carpenter & 30 & $2-(6.6)$ & 30 & $1-(3.3)$ & 30 & $2-(6.6)$ & 90 & $5-(5.5)$ \\
\hline Cycle mechanics & 30 & $9-(30)$ & 30 & $3-(10)$ & 30 & $5-(16.6)$ & 90 & $17-(18.8)$ \\
\hline Workers of factory & 100 & $25-(25)$ & 100 & 31-(31) & 100 & 35- (35) & 300 & $91-(30.3)$ \\
\hline Collector of hospital garbage & 15 & $10-(66)$ & 20 & $12-(6)$ & 20 & $15-(75)$ & 55 & $37-(67.2)$ \\
\hline Mason & 25 & $6-(24)$ & 25 & $1-(4)$ & 25 & $3-(12)$ & 75 & $10-(13.3)$ \\
\hline Mechanic of motor cycle & 50 & 7-(14) & 50 & $5-(10)$ & 50 & $8-(16)$ & 150 & $20-(13.3)$ \\
\hline Junior rank of police officials & 100 & $15-(15)$ & 100 & $20-(20)$ & 100 & 22-(22) & 300 & $57-(19)$ \\
\hline Painters & 25 & 7-(28) & 25 & $5-(20)$ & 25 & $8-(32)$ & 75 & $20-(26.6)$ \\
\hline Workshop workers & 100 & $18-(18)$ & 100 & $20-(20)$ & 100 & $25-(25)$ & 300 & 63-(21) \\
\hline Total & 485 & $101-20.8)$ & 490 & $99-20.2)$ & 490 & $123-(25.1)$ & 1465 & $323-(22)$ \\
\hline
\end{tabular}

Table-I. HCV prevalence in different occupations of rural Punjab

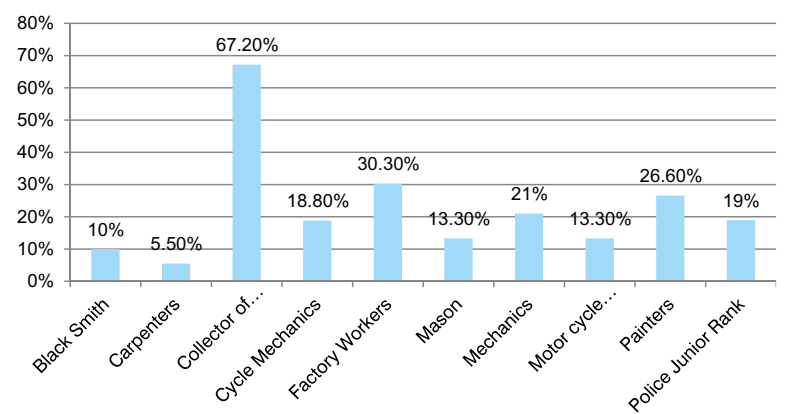

Figure-2. HCV prevalence in different occupations of rural Punjab

\section{DISCUSSION}

An epidemiological, cross sectional study was conducted to conclude the occupation based prevalence rate of hepatitis $\mathrm{C}$ in different areas of rural Punjab. It is important to mention that bulk of the studies related with hepatitis $\mathrm{c}$ prevalence are generally conducted in the urban or peri-urban areas. These studies are based on the data from health care facilities and purely community based studies are lacking. This may be due to the availability of financial, human and material resources in these areas. On the other side majority of the Pakistani population resides in the rural areas where access and affordability of the health care services is extremely lacking. Similarly these areas are generally neglected due to political and administrative reasons. Ultimately the socioeconomic status of this population is very low, leading to the poor hygiene and bad environmental conditions. Moreover the nutritional deficiencies, insecure health practices and health care seeking from the unqualified practitioners add a great danger to the situation. This study was based on the occupational categories of pure rural population which was included on the description of the district administration. Another point was the inclusion of the areas which were away from the public health facilities. As a result the original situation of these area regarding prevalence of HCV on the basis of different occupations is explored. Similarly majority of the studies are limited to a specific area or population and overall prevalence in Punjab is also lacking.

The results of this study conclude an overall HCV prevalence rate of (22\%) in different regions of the rural Punjab. These findings are in line with the results $(22.68 \%)$ of another similar population based study conducted in the rural population of Sumandri, Faisalabad. ${ }^{8}$ However the results are contrary to the findings of another study conducted in the same region concluding the prevalence rate of $(47.4 \%)$ in the patients visiting for treatment in a free eye camp. ${ }^{9}$ Similarly prevalence concluded in the present study is quite different from the results of some other population based studies from Islamabad, Sindh and Kashmir reporting the prevalence rate of (33\%), (28.6\%) and (7.5\%) respectively. ${ }^{10,11,12}$ The prevalence rate of $\mathrm{HCV}$ infection found in this study (67.2\%) was much higher in subjects related with the collection of hospital garbage where as the factory workers were having a prevalence rate of $(30.3 \%)$ and white wash painters $(26.6 \%)$ respectively. 
The results of present study regarding $\mathrm{HCV}$ prevalence in hospital garbage collectors are quite different from another similar study of Hepatitis $\mathrm{C}$ in garbage scavengers of Karachi in which the concluded prevalence was $8.5 \%$ only. ${ }^{17}$ It is worth mentioning that occupation based HCV prevalence studies are generally related to health care workers. However the present study has provided a base line data for the further investigation of the issue.

\section{CONCLUSION}

The infection by Hepatitis C Virus is a serious Public Health concern in the developing countries like Pakistan. The results of present study conclude cumulative occupation based prevalence rate of $(22 \%)$ in rural communities of Punjab, Pakistan. This is a high prevalence which need the immediate attention of the policy makers. The highest prevalence $(67.2 \%)$ is reported among the hospital garbage collectors followed by factory workers (30.3\%) and white wash painters $(26.6 \%)$ respectively. The lowest prevalence rate was observed in black smith workers (10\%) and carpenters $5.5 \%$ only. It is recommended to manage an occupation based hepatitis awareness and screening campaign for the affected and general community.

Copyright(C) 15 Oct, 2017.

\section{REFERENCES}

1. He S, Lin B, Chu V, Hu Z, Hu X, Xiao J, et al. Repurposing of the antihistamine chlorcyclizine and related compounds for treatment of hepatitis C virus infection. Sci Transl Med [Internet]. 2015;7(282):282ra49. Available from: http://www.ncbi. nlm.nih.gov/pubmed/25855495.

2. Alter M. Epidemiology of hepatitis $\mathbf{C}$ virus infection. World J Gastroenterol [Internet]. 2007;13(17):2436-41. Available from: http://www.wjgnet.com/1007-9327/full/ v13/i17/2436.htm.

3. Global Buden of Hepatitis C working Group. Global Burden of Disease (GBD) for Hepatitis C. J Clin Pharmacol [Internet]. 2004;44(1):20-9. Available from: htt p://www.ncbi.nlm.nih.gov/pubmed/14681338.

4. Vogel M, Rockstroh JK. Treatment of acute hepatitis C in HIV infection. J Antimicrob Chemother [Internet]. 2010;65(1):4-9. Available from: http://www.ncbi.nlm. nih.gov/pubmed/19861339.
5. Nepal A. Evidence of Hepatitis C Virus Infection and Associated Treatment in Nepal. J Mol Biomark Diagn [Internet]. 2016;7(2). Available from: https:// www.omicsonline.org/open-access/evidence-ofhepatitis-c-virus-infection-and-associated-treatment-innepal-2155-9929-1000270. php?aid=67123.

6. Tugwell BD, Patel PR, Williams IT, Hedberg K, Chai F, Nainan $O$, et al. Annals of Internal Medicine Article Transmission of Hepatitis C Virus to Several Organ and Tissue Recipients from an Antibody-Negative Donor. Ann Intern Med. 2005;143(9):648-54.

7. Saeed U, Waheed $Y$, Ashraf M. Hepatitis B and hepatitis C viruses: A review of viral genomes, viral induced host immune responses, genotypic distributions and worldwide epidemiology. Asian Pacific J Trop Dis. 2014;4(2):88-96.

8. Khalid A, Zahid M, Aslam Z, Bilal M, Haider A. SeroEpidemiology of Hepatitis B and C Virus in Rural Population of Tehsil Samundri, District Faisalabad, Pakistan. 2015;4(2):19-22.

9. Latif MZ, Hussain I, Nizami R, Dar U. Prevalence of Hepatitis B \& C in Patients Visiting a Free Eye Camp for Cataract Surgery at Jarranwala District Faisalabad. 2013;7(2):436-8.

10. Asad M, Ahmed F, Zafar H, Farman S. Frequency and determinants of hepatitis $B$ and $C$ virus in general population of Farash Town, Islamabad. Pakistan J Med Sci. 2015;31(6):1394-8.

11. Aziz S, Khanani R, Noorulain W, Rajper J. Frequency of Hepatitis $B$ and $C$ in rural and periurban Sindh. J Pak Med Assoc. 2010;60(10):853-7.

12. Area HS, Jammu A, Rauf A, Nadeem MS, Arshad M, Riaz $\mathrm{H}$, et al. Prevalence of Hepatitis $\mathbf{B}$ and $\mathbf{C}$ Virus in the General Population of. 2013;45(2):543-8.

13. Mohd Hanafiah K, Groeger J, Flaxman AD, Wiersma ST. Global epidemiology of hepatitis $C$ virus infection: New estimates of age-specific antibody to HCV seroprevalence. Hepatology. 2013;57(4):1333-42.

14. Khan S, Attaullah S, Ayaz S, Niaz Khan S, Shams S, Ali I, et al. Molecular epidemiology of hcv among health care workers of khyber pakhtunkhwa. Virol J [Internet]. 2011;8:105. Available from: http://www.pubmedcentral. nih.gov/articlerender.fcgi?artid $=3060846 \&$ tool $=p$ mcentrez\&rendertype $=$ abstract.

15. Sarwar J, Gul N, Idris M, Anis-ur-Rehman, Farid J, Adeel MY. Seroprevalence of hepatitis B and hepatitis $C$ in health care workers in Abbottabad. J Ayub Med Coll Abbottabad [Internet]. 2008;20(3):27-9. Available from: http://www.ncbi.nlm.nih.gov/pubmed/19610509. 
16. Ciorlia LADS, Zanetta DMT. [Hepatitis $\mathbf{C}$ in health care professionals: prevalence and association with risk factors]. Rev Saude Publica [Internet]. 2007;41(2):229-35. Available from: http://www.ncbi. nlm.nih.gov/pubmed/17384798

17. Coff C. Incorporation, Digestion and Incarnation. History. p. 1-9.

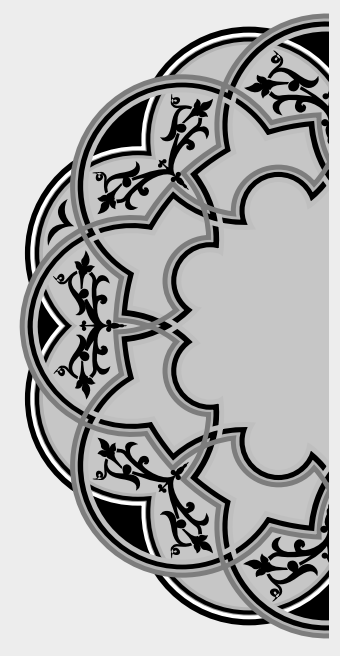

\title{
"Breakdowns can create breakthroughs."
}

\author{
Unknown
}

AUTHORSHIP AND CONTRIBUTION DECLARATION

\begin{tabular}{|c|l|}
\hline Sr. \# & \multicolumn{1}{|c|}{ Author-s Full Name } \\
\hline 1 & Syed Amir Gilani \\
2 & M. Ather Khan \\
3 & M. Zahid Latif \\
4 & Ahmed Azam Malik \\
\hline
\end{tabular}
Contribution to the paper
Research design, questionnaire, Data analysis and discussion.
Literature review, discussion and
Introduction, analysis, Resutls
Introduction, literature review

Author $=\mathbf{s}$ Signature final review. and write up. anddiscuussion

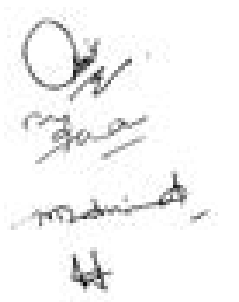

